RECONSTRUCTING RAWLS 



\section{RECONSTRUCTING RAWLS THE KANTIAN FOUNDATIONS OF JUSTICE AS FAIRNESS}

\section{R O B E R T S T T Y L O R}




\section{Library of Congress Cataloging-in-Publication Data}

Taylor, Robert S., 1968-

Reconstructing Rawls : the Kantian foundations of justice as fairness / Robert S. Taylor.

$$
\text { p. } \mathrm{cm} \text {. }
$$

Summary: "Compares the theories of John Rawls and Emmanuel Kant, and offers an internal critique and reconstruction of justice as fairness, reconceiving it as a comprehensive, universalistic Kantian liberalism"-Provided by publisher.

Includes bibliographical references (p. ) and index. ISBN 978-0-271-03771-4 (cloth : alk. paper)

$$
\text { 1. Justice. }
$$

2. Rawls, John, 1921-2002.

3. Kant, Immanuel, 1724-1804-Political and social views.

I. Title.

$$
\text { JC578.T39 } 2011
$$$$
320.01^{\prime} 1-\mathrm{dc} 22
$$

2010031598

\section{Copyright $\odot 2011$ The Pennsylvania State University \\ All rights reserved \\ Printed in the United States of America \\ Published by The Pennsylvania State University Press, \\ University Park, PA 16802-1003}

The Pennsylvania State University Press is a member of the Association of American University Presses.

It is the policy of The Pennsylvania State University Press to use acid-free paper. Publications on uncoated stock satisfy the minimum requirements of American National Standard for Information SciencesPermanence of Paper for Printed Library Material, ANSI Z39.48-1992.

This book is printed on Natures Natural, which contains $50 \%$ post-consumer waste. 